\title{
Holistic treatment of the patient in palliative care - The nurses view
}

Holistyczne podejście do pacjenta objętego o pieką paliatywną z perspektywy pielęgniarskiej

\author{
Bojana Filej’ ${ }^{1}$, Boris Miha Kaučičč, Boštjan Žvanut ${ }^{3}$, Mojca Saje ${ }^{4}$
}

\author{
1 Faculty of Health Sciences Novo mesto, Slovenia \\ ${ }^{2}$ College of Nursing in Celje \& Alma Mater Europaea - ECM, Slovenia \\ ${ }^{3}$ University of Primorska, Faculty of Health Sciences, Slovenia \\ ${ }^{4}$ Terme Krka Dolenjske Toplice, Slovenia
}

CORRESPONDING AUTHOR/AUTOR DO KORESPONDENCJ:

Bojana Filej

Faculty of Health Sciences Novo mesto, Slovenia

tel. 38640262452

e-mail: bojana.filej@gmail.com

ABSTRACT

Key words:

STRESZCZENIE

Słowa kluczowe:

\section{HOLISTIC TREATMENT OF THE PATIENT IN PALIATIVE CARE - THE NURSES VIEW}

Introduction. Man is a unique, unrepeatable whole in space and time and that is why he requires a holistic treatment, taking into account physical, psychological, social and spiritual factors. The balanced factors can ensure human well-being and his quality of life. Integrated treatment is especially important for patients in palliative care, which was the basic starting point of our research. In our research we wanted to establish whether the patients in palliative care are treated holistically from the perspective of the nurses and where are the specific aspects of palliative care (psychological, physical, social and spiritual) more visible - in the hospitals or in the home environment.

Material and methods. The questionnaire survey was based on the empirical quantitative methodology; a descriptive causal non-experimental method was used. The number of the included sample was 127 nurses ( 92 hospital nurses, 35 community nurses). To test the differences between the groups (hospital, community nursing), the single factor analysis of variance was used. All the research participants were ensured anonymity and they had the right to withdraw from the study before or during the questionnaire completion.

Results. The physical aspect of the treatment was statistically significantly higher assessed by nurses in a hospital setting $(\bar{X}=3.83$; $s=1.012 ; p=0.042$ ). The psychological and spiritual aspects were higher assessed in community nursing setting and social aspect in hospital setting.

Conclusions. Our research has highlighted the shortcomings of the holistic approach in palliative care. Nurses need in-depth knowledge and skills as well as practice within each holistic domain to perform quality treatment of palliative patients.

holistic nursing, nurse, hospital, community nursing, palliative care

\section{HOLISTYYCZNE PODEJŚCIE DO PACJENTA OBJĘHECO OPIEKA PALIATYWNĄ Z PERSPEKIYWY PIELEZGNIARSKIE]}

Wprowadzenie. Człowiek jest wyjątkową i niepowtarzalną całością w czasoprzestrzeni, dlatego wymaga holistycznej opieki, w której brane są pod uwagę jego czynniki fizyczne, psychologiczne, społeczne i duchowe. Te zrównoważone czynniki zapewniają mu dobre samopoczucie oraz jakość życia. Zintegrowane leczenie jest szczególnie ważne przy opiece paliatywnej nad pacjentami, która stanowi punkt wyjścia dla niniejszej pracy. Badanie miało na celu wykazać czy pacjenci objęci opieką paliatywną są według pielęgniarek/pielęgniarzy traktowani całościowo oraz gdzie poszczególne aspekty opieki paliatywnej (fizyczne, psychologiczne, społeczne i duchowe) są bardziej widoczne - w szpitalach czy w środowisku domowym.

Materiał i metodyka. Przeprowadzono badania ankietowe i zastosowano metodę analizy ilościowej zebranego materiału. Liczba badanych wyniosła 127 pielęgniarek/pielęgniarzy (92 szpitalnych i 35 środowiskowych). Do zbadania różnic pomiędzy grupami (pielęgniarstwo szpitalne, środowiskowe) użyto jednoczynnikowej analizy wariancji. Wszyscy uczestnicy badania zostali zapewnieni 0 anonimowości oraz o prawie do wycofania się z uczestnictwa w badaniu lub jego w trakcie.

Wyniki. Aspekt fizyczny leczenia był statystycznie istotnie wyżej oceniony przez pielęgniarki i pielęgniarzy pracujących w szpitalach $(\bar{X}=3,83 ; s=1,012 ; p=0,042)$. Aspekty psychologiczny i duchowy zostały ocenione wyżej przez pielęgniarki i pielęgniarzy środowiskowych, zaś aspekt społeczny przez respondentów pracujących w szpitalach.

Wnioski. Badanie pokazało pewne niedociągnięcia w holistycznym podejściu do pacjenta objętego opieką paliatywną. Pielęgniarki i pielęgniarze potrzebują pogłębionej wiedzy i umiejętności, jak również praktyki w każdym holistycznym aspekcie aby móc zapewniać pacjentom najlepszą jakość opieki paliatywnej.

holistyczna opieka pielęgniarska, pielęgniarka, szpital, pielęgniarstwo środowiskowe, opieka paliatywna 


\section{INTRODUCTION}

Integrated treatment of patients means treating patients as a whole, considering the integration of body, mind and spirit, physical and psychological well-being and socio-cultural influences in the ever changing environment [1]. Humans have unique personalities with their own history, feelings, thoughts, lifestyles, problems, expectations and desires [2]. A person should not only be the subject of interest when it comes to a physical symptom or as a single part, but as a whole [3]. Holistic care is only possible if there is the expertise of specialists who share their knowledge with other experts [4] because through such cooperation, different disciplines will be in unison and will develop with respect to their own practices [5]. Holistic nursing has its own body of knowledge, developed standards of practice and evidence-based research [6].

The body (bodily, physical and biological perspective) is nothing else but an arrangement of mechanical systems composed of cells, tissues and biochemistry; such body is understood as a machine without the mind and soul [7]. The mental (psychic and psychological) aspect is based on the action of psychic processes, of which the most important processes include thinking, feeling, memory, perception, temperament and personal characteristics. The social (socio-cultural) aspect emphasises that the society and culture influence the intellectual and emotional development of the individual; so does religion. We must thus differentiate between culture and religion while being aware of their interconnectedness. The spiritual aspect is crucial to our lives and helps us clarify who and what we are; it helps us clarify the purpose of our lives and our internal resources [8]. Spirituality is the inherited and inalienable human dimension that is the least known and researched by people; it is invisible to external eyes and hidden. If there are no spiritually awakened individuals, the society will face the spread of rapacity, competition, exploitation of fellow human beings and nature, mistrust, fear and hatred [9].

Holistic care is a concept that is still not entirely clear; a concept that is defined differently and poorly understood [7]. This concept is very also often subjective, especially from the point of view of those who need comprehensive treatment. Lunder [10] believes that the majority of health professionals are primarily focused on the technical challenges and solutions, what leaves them little time for listening to comprehensive needs of patients or their relatives.

Each human has its own, unique way of life from birth to death, of which he is also aware. He is aware that the path will end one day due to age or some incurable illness, perhaps even sooner [11]. Care at the end of one's life is very important. The World Health Organisation [12] defines palliative care as an approach toward patients and their families in order to improve their quality of life in case of an incurable illness. As stated by Healy, Israel, Charles and Reymond [13], the palliative care is intended for people to live and die with grace in a decent environment they have chosen.

The goal of our study was to determine whether the patients in palliative care, which is currently present in the
Slovenian area, were treated in a holistic manner from the physical, psychological, social and spiritual point of view and in which environment (hospital - $\mathrm{H}$, home - $\mathrm{CN}$ ) are the stated aspects of the holistic care more complex. The survey was conducted in the Dolenjska region, in the southeastern part of Slovenia in 2014.

\section{MATERIALS AND METHODS}

The survey was based on the empirical quantitative methodology, a descriptive causal non-experimental method was used.

In order to collect the data, we produced a survey questionnaire on the basis of literature. In the first part of the questionnaire, we collected general demographic information about the respondents and data on the frequency of treatment of palliative patients, whereas in the second part, we collected data on the opinion of respondents about the holistic treatment of patients in palliative care. The statements were grouped into categories: the physical aspect which consisted of eleven statements; the psychological aspect - eight statements, the social aspect three statements and the spiritual aspect - four statements. The respondents had to assess the statements after 5-level Likert scale of agreement for each single statement (1 I do not agree at all, 2 - I partially agree 3 - I neither agree nor disagree, 4 - I partially agree, 5 - I totally agree).

The reliability of the questionnaire was tested with Cronbach coefficient alpha, which was equal to 0.86 , which means that there is a high reliability of the questionnaire and the collected data.

In the research a non-random purpose pattern was used. The survey questionnaire was sent to 125 hospital nurses and 37 community nurses. The number of the included sample was 162 nurses. The number of filled questionnaires was 127 , which represents $78,4 \%$ realization of the sample ( $92-73,6 \%$ from hospital, $35-94,6 \%$ from community nursing). $90,5 \%$ of the respondents were of the female gender, $36,2 \%$ had up to ten years of work experience and treated palliative patients several times a month $(29,9 \%)$.

The participation in the survey was voluntary and anonymous, all participants had the right to withdraw from the study before or during the questionnaire completion. The data was analysed with the programme SPSS 20.0. For testing the assumptions about the arithmetic differences in arithmetic mean, the single factor analysis variance was used in order to determine whether the differences between the samples are explicable as statistical deviations within the same population (hospital, community nursing; physical, mental, social, spiritual aspect). The statistical characteristic was checked at the level of $5 \%$ risk ( $p=0.05)$.

Ethical approval was obtained by the Faculty of Health Sciences Novo mesto (number: VŠZ-129/2012, date 19.6.2012). There was also an agreement of the regional hospital and community nursing departments. 


\section{RESULTS}

Table 1 shows the estimates of agreement with the statements defined as the physical (eleven statements) and psychological (eight statements) aspects of palliative care.

- Tab. 1. The physical and psychological aspects of palliative care.

\begin{tabular}{|c|c|c|c|c|c|c|c|}
\hline & & H & & & CN & & \\
\hline Statements & $\mathbf{n}$ & $\bar{X}$ & s & n & $\bar{X}$ & $\mathbf{s}$ & $\mathbf{P}$ \\
\hline $\begin{array}{l}\text { I implement the care } \\
\text { of a palliative patient } \\
\text { holistically. }\end{array}$ & 91 & 4.32 & 0.855 & 35 & 4.40 & 0.736 & 0.621 \\
\hline $\begin{array}{l}\text { I recognize the most } \\
\text { frequent symptoms } \\
\text { in palliative care. }\end{array}$ & 92 & 3.92 & 0.815 & 35 & 4.00 & 0.970 & 0.657 \\
\hline $\begin{array}{l}\text { I know the side-effects } \\
\text { of opioides. }\end{array}$ & 91 & 3.78 & 0.854 & 35 & 3.94 & 0.802 & 0.332 \\
\hline $\begin{array}{l}\text { I know how to act } \\
\text { appropriatelly or advise } \\
\text { the relatives on obstipation } \\
\text { as side-effects of opioides. }\end{array}$ & 92 & 4.11 & 0.870 & 35 & 4.51 & 0.612 & 0.013 \\
\hline $\begin{array}{l}\text { Dyspnea is } \\
\text { a frequent symptom. }\end{array}$ & 91 & 4.14 & 0.811 & 35 & 4.43 & 0.698 & 0.068 \\
\hline $\begin{array}{l}\text { Delirium is an } \\
\text { unrecognized } \\
\text { companion in the } \\
\text { terminal phase. }\end{array}$ & 89 & 3.37 & 0.970 & 35 & 3.31 & 1.078 & 0.778 \\
\hline $\begin{array}{l}\text { More food in cachexia } \\
\text { patients prevents } \\
\text { further loss of weight. }\end{array}$ & 92 & 3.25 & 1.145 & 35 & 2.46 & 0.919 & 0.001 \\
\hline $\begin{array}{l}\text { It is necessary to } \\
\text { prevent pressure ulcers } \\
\text { even in a dying patient. }\end{array}$ & 90 & 4.43 & 0.972 & 35 & 4.63 & 0.490 & 0.260 \\
\hline $\begin{array}{l}\text { At high doses of opioides } \\
\text { addiction appears. }\end{array}$ & 91 & 3.48 & 1.158 & 35 & 2.86 & 1.192 & 0.008 \\
\hline $\begin{array}{l}\text { At longer pain therapy } \\
\text { with opioides, tolerance } \\
\text { develops. }\end{array}$ & 91 & 3.80 & 0.945 & 35 & 3.69 & 1.022 & 0.546 \\
\hline $\begin{array}{l}\text { Palliative care is a } \\
\text { synonim for terminal } \\
\text { phase. }\end{array}$ & 90 & 3.52 & 1.019 & 35 & 3.71 & 1.045 & 0.349 \\
\hline $\begin{array}{l}\text { I respect the right of the } \\
\text { patient to decide for } \\
\text { himself. }\end{array}$ & 92 & 4.29 & 0.871 & 35 & 4.43 & 0.979 & 0.452 \\
\hline $\begin{array}{l}\text { I explain in } \\
\text { a comprehensible } \\
\text { manner the processes } \\
\text { and procedures that } \\
\text { will be implemented. }\end{array}$ & 91 & 4.53 & 0.794 & 35 & 4.86 & 0.430 & 0.001 \\
\hline $\begin{array}{l}\text { I understand the } \\
\text { periods of anger and } \\
\text { agression in a patient } \\
\text { in palliative care. }\end{array}$ & 92 & 4.21 & 0.833 & 35 & 4.14 & 0.810 & 0.699 \\
\hline $\begin{array}{l}\text { I recognize the feelings } \\
\text { of fear in a dying patient. }\end{array}$ & 91 & 4.02 & 0.843 & 35 & 4.03 & 0.747 & 0.968 \\
\hline $\begin{array}{l}\text { I provide professional } \\
\text { help for patient who } \\
\text { expresses suicide thoughts. }\end{array}$ & 91 & 4.20 & 0.872 & 35 & 3.86 & 1.033 & 0.065 \\
\hline $\begin{array}{l}\text { I understand patient's } \\
\text { plea for merciful death. }\end{array}$ & 91 & 3.97 & 1.110 & 35 & 3.80 & 0.994 & 0.438 \\
\hline $\begin{array}{l}\text { I feel helpless when } \\
\text { nursing the dying person. }\end{array}$ & 92 & 3.47 & 1.084 & 35 & 3.63 & 0.877 & 0.433 \\
\hline $\begin{array}{l}\text { I often face ethical } \\
\text { dilemmas when working } \\
\text { with the dying patients. }\end{array}$ & 92 & 3.68 & 1.016 & 35 & 3.97 & 0.857 & 0.141 \\
\hline
\end{tabular}

Legend: $\mathrm{n}$ - number, $\overline{\mathrm{x}}$ - average, $\mathrm{s}$ - standard deviation, $\mathrm{p}$ - statistical significance, $\mathrm{H}$ - hospital, $\mathrm{CN}$ - community nursing
Both groups of nurses mostly agree with the statement „I explain to the patient in a comprehensible way processes and procedures that will be implemented" $(\mathrm{H}: \overline{\mathrm{X}}=4.53$, $\mathrm{s}=0.794$; $\mathrm{CN}: \bar{\chi}=4.86, \mathrm{~s}=0.430)$ and least agree with the statement „More food in cachexia patients prevents further loss of weight" ( $\mathrm{H}: \bar{X}=3.25, \mathrm{~s}=1.145 ; \mathrm{CN}: \bar{X}=2.46, \mathrm{~s}=0.919)$. In both statements the statistically significant difference is $(p=0.001)$, which means that the nurses in the hospital agree more with the first statement and community nurses with the second statement. A statistically significant difference $(\mathrm{p}=0.013)$ occurrs also in the statement „I know how to act appropriatelly or to advise the relatives on the obstipation as a side effect of opioid use”, which is more agreed by the community nurses. The statement "At high doses of opioids addiction appears" is statistically significantly more agreed by the hospital nurses $(\mathrm{p}=0.008)$.

In order to evaluate the social aspects of palliative care, we have designed three statements and for spiritual aspects, four statements and put them in the questionnaire (Tab. 2).

Tab. 2. The social and spiritual aspects of palliative care.

\begin{tabular}{|l|c|c|c|c|c|c|c|}
\hline \multicolumn{1}{|c|}{ Statements } & $\mathbf{n}$ & $\bar{X}$ & $\mathbf{s}$ & $\mathbf{n}$ & $\bar{X}$ & s & P \\
\hline $\begin{array}{l}\text { I respect the } \\
\text { importance } \\
\text { of the family. }\end{array}$ & 92 & 4.32 & 0.889 & 35 & 4.49 & 0.853 & 0.331 \\
\hline $\begin{array}{l}\text { The remission of a } \\
\text { palliative patient into } \\
\text { home environment is } \\
\text { planned and organized. }\end{array}$ & 91 & 3.89 & 1.080 & 35 & 3.49 & 1.173 & 0.068 \\
\hline $\begin{array}{l}\text { The patient and } \\
\text { relatives get enough } \\
\text { information for the } \\
\text { implementation of } \\
\text { palliative care in the } \\
\text { home environment. }\end{array}$ & 92 & 3.26 & 1.098 & 35 & 2.91 & 0.887 & $\mathbf{0 . 0 3 3}$ \\
\hline $\begin{array}{l}\text { When informing the } \\
\text { patient Itake into } \\
\text { consideration his } \\
\text { medical condition. }\end{array}$ & 91 & 4.40 & 0.773 & 35 & 4.66 & 0.725 & 0.086 \\
\hline $\begin{array}{l}\text { I cultivate a respectable } \\
\text { relationship and } \\
\text { communication } \\
\text { with the patients. }\end{array}$ & 92 & 4.47 & 0.718 & 35 & 4.69 & 0.530 & 0.104 \\
\hline $\begin{array}{l}\text { The spiritual needs of } \\
\text { a palliative patient are } \\
\text { better taken care of in } \\
\text { the home environment. }\end{array}$ & 92 & 4.05 & 1.073 & 35 & 3.69 & 0.900 & 0.074 \\
\hline $\begin{array}{l}\text { The patient's } \\
\text { acceptance of the } \\
\text { disease facilitates } \\
\text { the process of dying. }\end{array}$ & 92 & 4.20 & 0.917 & 35 & 4.34 & 0.684 & 0.390 \\
\hline
\end{tabular}

Legend: $n$ - number, $\bar{x}$ - average, $s$ - standard deviation, $p$ - statistical significance, $H$ - hospital, $\mathrm{CN}$ - community nursing

Among the interviewed nurses in the hospital and community nursing, there is no difference between the greatest and the lowest agreement with the statements. In the statement „The patient and relatives get enough information for the implementation of palliative care in the home environment" $(\mathrm{H}: \bar{X}=3.26, s=1.098 ; \mathrm{CN}: \overline{\mathrm{X}}=2.91$, $s=0.887$ ), there is a statistically significant difference in agreement $(\mathrm{p}=0.033)$, the nurses in hospital environment agree with it more. 
Hereinafter we combined the results of all the statements for every single aspect of the treatment and all the aspects of the holistic treatment of patient in palliative care (Tab. 3).

Tab. 3. The aspects of palliative care.

\begin{tabular}{|l|c|c|c|c|c|}
\hline & \multicolumn{2}{|c|}{ H } & \multicolumn{2}{c|}{ CN } & \\
\hline \multicolumn{1}{|c|}{ The aspects of treatment } & $\bar{X}$ & S & $\bar{X}$ & S & P \\
\hline physical aspect & 3.83 & 1.012 & 3.79 & 1.090 & $\mathbf{0 . 0 4 2}$ \\
\hline psychological aspect & 4.05 & 0.984 & 4.09 & 0.925 & 0.516 \\
\hline social aspect & 3.82 & 1.111 & 3.63 & 1.171 & 0.193 \\
\hline spiritual aspect & 4.28 & 0.893 & 4.34 & 0.820 & 0.455 \\
\hline
\end{tabular}

Legend: $x$ - average, $\bar{s}$ - standard deviation, $p$ - statistical significance, $\mathrm{H}$ - hospital, $\mathrm{CN}$ - community nursing

The physical aspect of the treatment was statistically significantly $(\mathrm{p}=0.042)$ higher assessed by nurses in hospital environment. The differences in the assessment of other aspects of palliative care were not statistically significant. The psychological aspect of treatment is somewhat higher assessed in the community nursing $(\bar{X}=4.09, s=0.925)$, as well as is the spiritual aspect $(\bar{X}=4.34$, $s=0.820$ ). The social aspect is, on the other hand, assessed higher by nurses in hospital $(\bar{x}=3.82 \mathrm{~s}=1.111)$.

\section{DISCUSSION}

When assessing the physical aspects of palliative care, the nurses agree mostly with the statement that it is important to prevent pressure ulcers also in dying patients, because as stated by Hendrichova et al. [14], pressure ulcers represent an important problem in palliative care as they intensify the suffering of the patients and reduce their quality of life. In the survey 414 cancer patients cared for in the palliative care during a period of 6 months were included. The researchers stated that pressure ulcers appeared in elderly people regardless of their gender and that the treatment of such patients was statistically significantly prolonged. In addition, the patients who used opioids and sedative drugs inhibiting spontaneous movements were more exposed to the risk of developing pressure ulcers. Maida et al. [15] followed 170 patients and claimed that the occurrence of pressure ulcers is correlated with reduced survival of patients.

The respondents at least agree with the statement "More food in cachexia patients prevents further weight loss". Holmes [16] indicates the importance of nutrition in order to maintain the quality of life in palliative care and in his study on the principles of nutrition in the palliation of long-term conditions, he points out that it is clear that nutrition means more than just refuelling the body, it also has an important psychological, social, spiritual and cultural role.

Kwon et al. [17] state that pain is a common symptom that diminishes the quality of life of the patients, however, it still is not sufficiently addressed. Eyigor [18] in his study observes that $34.3 \%$ of surveyed medical students believe that the use of opioids was insufficient in cancer patients, whereas $54.3 \%$ of them stated that pain management was inadequate. Also, $66.5 \%$ of students in agree that the claim that the prolonged use of opioids can cause addiction does not hold true, whereas $54.3 \%$ of them agree that the use of laxatives effectively prevents opioid-induced constipation. Clark et al. [19] have also studied the impact of opioids on the prescribing of laxatives in hospitalized patients in palliative care and by studying 211 patients established that constipation is caused by several factors, the opioides being only one of them, but the condition gets worse if the dose of opioids increases.

Constipation has been described as one of the most distressing and uncomfortable symptoms experienced by people who require palliative care [20]. In our survey the nurses in hospital agree more with the statement that high doses of opioides cause addiction than the community nurses. On the other hand, the community nurses agree more with the statement that they are able to act appropriatelly or to advise relatives on the obstipation as a side effect of opioids.

When assessing the psychological aspects of palliative care, our survey revealed that one of the most important nurses' activities is explaining to the patient in a comprehensible way the processes and procedures that will be implemented. The importance of informing the patients about their treatment is also emphasized in the research by Disler, Jones [21], who analysed 68 published researches and established that the patients' lack of understanding and access to information were also consistently identified in the end-stage, therefore they point out that the patients clearly require involvement and support from the health-care professionals in the community. The study carried out by Moir et al. [22] on the sample of 60 nurses has on the other hand revealed that work experience or seniority of the nurses has also an important effect on the quality of passing on the information.

Further on, our survey shows that nurses do not feel helpless when nursing the dying. Verschuur et al. [23] state that it is difficult to predict the life expectancy and therefore, they do not want to strip the patient of all hope. They also state that patients and relatives sometimes exert considerable pressure on professionals not to give up on the patient, although most patients appreciate the discussions about their personal future [24]. Also Eyigor [18] in his survey of 192 students of medicine notes that $55.4 \%$ of the students consider it difficult to tell someone that he or she is going to die. Grigorean et al. [25] also state that one third of the physicians and one half of the nurses in such situations experience feelings of uselessness and devastation.

It can be concluded that the nurses in the hospital as well as the community nurses have the same opinion that patients and families are not provided with enough information for the implementation of palliative care in the home environment. A similar thing is noted also by Hunstad, Foelsvik Svindseth [26], who conducted a qualitative research using a system theory among seven spouses who cared for their relatives at home and showed that none of them has been adequately informed about the implementation of palliative care at home. All included in the research have insisted on the importance of contac- 
ting the competent persons who would be able to provide assistance at any time. They also highlighted the necessity of interprofessional collaboration and dialogue between different professionals. Bergdahl et al. [27] also noted that the care provided should be team-based and holistic.

In our study, both groups of nurses to the least degree agreed with the statement that the spiritual needs of the patient are better cared for in home environment. Hunstad et al. [26] state that the majority of studies report an increased quality of life when spiritual needs are met and that providers of home-based care should be aware of not only physical care importance, but also psychological, spiritual, and psychosocial ones of all family members.

The findings of our research show that in the community environment the most important aspect of care is the spiritual one, in contrast to the findings of Rose, Glass [28], who state that the most important aspect of community nurses is the implementation of clinical care. Our research has also shown that the physical aspects of treatment are more present in the hospital environment than in the community nursing, whereas Rose, Glass [28] observed that in the end-stage care nurses were often more focused on routine physical tasks than on the psychological aspects. They argue as well that even if the psychological support is poorly defined, it is nevertheless imperative to holistic care. Bradley et al. [29] on the other hand, on the sample of 8 semistructure interviews established that it depends on the individual which aspect of the treatment he or she gives priority to - the social or physical. However, clinical judgment remains a valuable part of the decision-making process, allowing to focus on the changing needs of patient and their caregivers. The loss of social role and physical restriction often cause psychological distress, depression, anxiety and frustration, and an overall poor quality of life [21]. The goal of palliative care, as stated by Freeman, Price [30], is, however, irrespective of the disease management at the end-of-life and the increased comfort and quality of life.

Our research has highlighted the shortcomings of the holistic approach of the studied nurses who performed palliative care in hospital and community nursing. There are obviously more reasons standing behind and the most important is certainly the lack of knowledge on implementation of holistic treatment in palliative care. Therefore, it is necessary to deepen the knowledge of holism and individual factors in nursing theory and practice in order to ensure quality of the palliative patients treatment.

The limitations of our research are in the limited number of statements which we have designed for each aspect of the holistic treatment, as well as in a limited number of the nurses surveyed, since the included sample was regionally limited. For that reason the results cannot be generalized to a wider circle of nurses, as well as not to a broader regional (Slovenian) place.

\section{CONCLUSIONS}

A holistic treatment of a palliative patients includes meeting their physical, psychological, social and spiritual needs in order to identify and respond to disruptive symptoms of palliative care. If we do not detect one of the patient's needs, we cannot define it and cannot take care of it approppriatelly, therefore in such case we cannot talk about a holistic palliative treatment.

A dying person does not require an active treatment of the threatening disease. What he or she needs, is an effective release of all the symptoms of the disease and the presence of his nearest and dearest who will offer him or her an all - round help and support.

\section{REFERENCES}

1. McEvoy L, Duffy A. Holistic practice - A concept analysis. Nurse Education in Practice. 2008; 8(6):412-419.

2. Hajdinjak G, Meglič R. Sodobna zdravstvena nega. Ljubljana: Univerza v Ljubljani, Zdravstvena fakulteta, 2012, s. 1-364.

3. Holizem, http//www.holist.eu/holizem.html, [accessed: 26. 7. 2012]

4. Carrier JM, Kendall I. Professionalism and interprofessionalism in health and community care: some theoretical issues. [in:] Owens P, Carrier J, Horder J, red. Interprofessional Issues in Community and Primary Health Care. London: Macmillan, 1995.

5. Filej B, Kaučič BM. Holistic nursing practice. South Eastern Europe Health Sciences Journal. 2013; 3(1):1-7.

6. Katz Ressler P. What is »Holistic Nursing«?, http://www.nursetogether.com, [accessed: 28. 8. 2015]

7. Tjale $A A, B$ ruce $B$. A concept analysis of holistic nursing care in paediatric nursing. Curationis. 2007; 30(4):45-52.

8. Filej B, Kaučič BM. Koncepti metaparadigme v holistični obravnavi. [in:] Kaučič BM, Plank D, Preskar Planko A, Esih K, red. Sodelovanje strokovnjakov v paliativnem timu za celostno obravnavo pacientov in svojcev. Celje: Visoka zdravstvena šola v Celju; 2015, s. 12-20.

9. Periček Krapež V. Se duhovnost pojavi kar sama od sebe?; 2011, http://www. karmaplus.net/index2, [accessed: 1.9.2011]

10. Lunder U. Paliativna oskrba v bolnišnici - organizacijske značilnosti, strokovne usmeritve. [in:] Lunder U. red. Izbrane teme paliativne oskrbe in praktične delavnice. Ljubljana: Ministrstvo za zdravje Republike Slovenije, Bolnišnica Golnik - klinični oddelek za pljučne bolezni in alergijo, v okviru EU Projekt OPCARE9; 2011, s. 6-10.

11. Saje M. Paliativna oskrba - vidik kakovosti ob izteku življenja. Magistrsko delo. Visoka šola za zdravstvo Novo mesto; 2013.

12. World Health Organization. WHO Definition of Palliative Care. 2005, http://www. who.int/cancer/palliative/definition/en/, [accessed: 30.5. 2015]

13. Healy S, Israel F, Charles MA, Reymond L. An educational package that supports laycarers to safely manage breakthrough subcutaneous injections for home-based palliative care patients: Development and evaluation of a service quality improvement. Palliative Medicine. 2013; 27(6):562-70. doi: $10.1177 / 0269216312464262$.

14. Hendrichova I, Castelli M, Mastroianni C, et al. Pressure ulcers in cancer palliative care patients. Palliative Medicine. 2010; 24(7):669-73. doi: 10.1177/0269216310376119.

15. Maida V, Ennis M, Kuziemsky C, Corban J. Wounds and survival in noncancer patients. Journal of Palliative Medicine. 2010; 13(4):453-9. doi: 10.1089/jpm.2009.0260

16. Holmes $S$. Principles of nutrition in the palliation of long-term conditions. International Journal of Palliative Nursing. 2011; 17(5):217-22. doi: https://dx.doi. org/10.12968/ijpn.2011.17.5.217.

17. Kwon JH, Hui D, Chisholm G, et al. Experience of barriers to pain management in patients receiving outpatient palliative care. Journal of Palliative Medicine. 2013; 16(8):908-14. doi: 10.1089/jpm.2012.0610.

18. Eyigor $S$. Fifth-year medical students' knowledge of palliative care and their view on the subject. Journal of palliative medicine. 2013; 16(8):941-6. doi: 10.1089/ jpm.2012.0627.

19. Clark K, Lam LT, Agar M, et al. The impact of opioids, anticholinergic medications and disease progession on the prescription of laxatives in hospitalized palliative care patients: a retrospective analysis. Palliative Medicine. 2010; 24(4):410-8. doi: 10.1177/0269216310363649

20. Sykes N. Issues in palliative care research. Oxford University Press, New York; 2003.

21. Disler $R$, Jones $A$. District nurse role in end-stage COPD: a review. British Journal of Community Nursing. 2010; 15(9):428-33. doi: http://dx.doi.org/10.12968/ bjcn.2010.15.9.78100.

22. Moir C, Roberts R, Martz K, et al. Communicating with patients and their families about palliative and end-of-life care: comfort and educational needs of nurses. 
International Journal of Palliative Nursing. 2015; 21(3):109-12. doi: 10.12968/ ijpn.2015.21.3.109.

23. Verschuur EML, Groot MM, van der Sande R. Nurses' perceptions of proactive palliative care: a Dutch focus group study. Internationa Journal of Palliative Nursing. 2014; 20(5):241-5. doi: https://dx.doi.org/10.12968/ijpn.2014.20.5.241

24. Piers RD, van Eechoud IJ, Van Camp S. Advance care planning in terminally ill and frail older persons. Patient Educ Couns. 2013; 90(3):323-9. doi: 10.1016/j.pec.2011.07.008

25. Grigorean VT, Nita GR, Sandu AM, et al. Blockage of communication with the patient's family-clinical and psycho-emotional implications. Acta Medica Transilvanica. 2014; 19:127-30.

26. Hundstad I, Foelsvik Svindseth M. Challenges in home-based palliative care in Norway: a qualitative study of spouses' experiences. International Journal of Palliative Nursing. 2011; 17(8):398-404. doi: https://dx.doi.org/10.12968/ ijpn.2011.17.8.398.

27. Bergdahl E, Benzein E, Ternestedt BM, et al. Co-creating possibilities for patients in palliative care to reach vital goals - a multiple case study of home-care nursing encounters. Nursing Inquiry. 2013; 20(4):341-51. doi: 10.1111/nin.I2022.

28. Rose J, Glass N. Nurses and palliation in the community: the current discourse. International Journal of Palliative Nursing. 2006; 12(12):588-94. doi: https://dx.doi. org/10.12968/ijpn.2006.12.12.22545.

29. Bradley SE, Frizelle D, Johnson M. Why do health professionals refer individual patients to specialist day hospice care? Journal of palliative medicine. 2011; 14(2):133-8. doi: 10.1089/jpm.2010.0372.

30. Freeman D, Price D. ABC of chronic obstructuve pulmonary disease: primary care and palliative care. British Medical Journal. 2006; 333(7560):188-90. doi: https://dx.doi. org/10.1136\%2Fbmj.333.7560.188.
Manuscript received: 19.12 .2016

Manuscript accepted: 24.01.2017

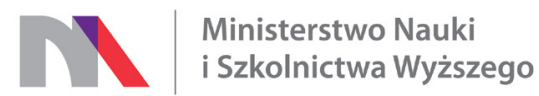

„Konsultacje z zagranicznymi naukowcami i wprowadzenie dwujęzycznych (j. polski/angielski) treści do czasopisma Pielęgniarstwo XXI wieku" finansowane w ramach umowy 547/P-DUN/2016 ze środków Ministra Nauki i Szkolnictwa Wyższego przeznaczonych na działalność upowszechniającą naukę. 